\title{
Primavera de 2011 Movimento dos editores
}

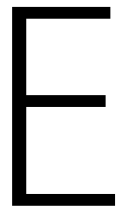

ste segundo semestre de 2011 se caracterizou no mundo editorial da enfermagem brasileira como uma primavera especial em que houve um movimento de editorese organizações científicas em prol da defesa do conhecimento produzido por nossos pesquisadores e de seus veículos de divulgação.

De um lado, as propostas implementadas pelo Fórum Nacional de Editores de Revistas Científicas de Enfermagem da Aben, como as sugestões à Capes para o financiamento dos periódicos e, ainda a possibilidade de criação de consórcios como forma de diminuir custos e aumentar a visibilidade das revistas, demonstraram a vitalidade da estratégia/encontro que já tem história de mais de uma década de reuniões. As propostas foram sustentadas nesse

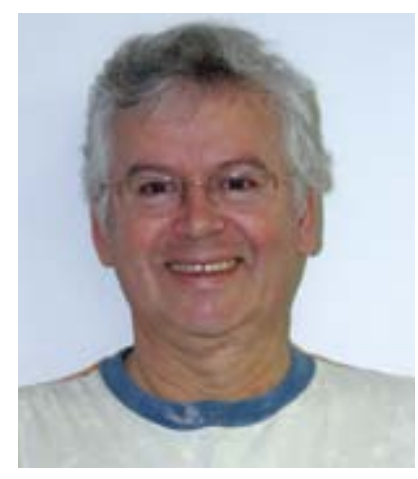
espaço coletivo e, serão levadas pelos pesquisadores aos órgãos deliberativos de pesquisa.

De outro, o III Fórum Latino-Americano de Editoração Científica em Enfermagem e Saúde, evento regular da Escola de Enfermagem de Ribeirão Preto da Universidade de São Paulo, espaço de discussão que reúne editores da enfermagem, profissionais de outras carreiras da saúde, órgãos de governo e organizações de categoria profissional para discutir políticas, estratégias e desafios da busca contínua da excelência da editoração científica, envolvendo em âmbito internacional a AméricaLatina, África Portuguesa, Portugal e Espanha. Neste Fórum foram discutidos os critérios de financiamento dos periódicos de enfermagem e os resultados encaminhados para a Capes.

Também neste final de ano, a Associação Brasileira de Editores Científicos-ABEC realizou seu tradicional encontro anual, que teve como resultado uma parceria da organização com a Scielo para a realização de uma pesquisa envolvendo todos os editores. Cujo produto deverá subsidiar importantes projetos para o desenvolvimento dos periódicos brasileiros.

Na área de enfermagem, a Capes optou por financiar os seguintes periódicos: Revista Brasileira de Enfermagem, o mais antigo da profissão no país e a Revista Gaúcha de Enfermagem, $5^{\circ}$ periódico a ser criado. A escolha deu-se sobre esses porque são os que têm a melhor indexação e estão posicionados num patamar próximo a qualificação máxima do Qualis.

Por certo, os editores desses periódicos terão as responsabilidades de implementar mudanças significativas de maneira que suas revistas possam alçar melhores posições no campo da publicação científica.

Algumas questões têm mobilizado as pautas desses encontros, como a formação de um público leitor que sustente os periódicos, visto que o número de assinantes dos periódicos é muito baixo, ocorrendo principalmente pelo compromisso de publicação; outra demanda importante é o crescimento da produção da pós-graduação, incapaz de ser drenada por nossos veículos de divulgação e ainda, o surgimento de novos periódicos, os quais precisam de uma ação conjunta dos pesquisadores e editores para seu fortalecimento.

Penso, que essas e outras questões estão postas e devem fazer parte da agenda do editores de enfermagem no Brasil. Bem como de nossas organizações profissionais.

Joel Rolim Mancia Editor-chefe 